\title{
A Probe into the Main Demotivating Factors among Iranian EFL Learners
}

\author{
Parviz Alavinia (Corresponding author) \\ Faculty of Humanities and Letters, Urmia University \\ Vajfajr 2 Blvd., Urmia, West Azerbaijan, Iran \\ Tel: 98-0441-336-2008 E-mail: pevinia2006@yahoo.com
}

\author{
Reza Sehat \\ Maragheh Azad University \\ PO box 345, Shahid Derakhshi Blvd., Maragheh, Iran \\ Tel: 98-0421-325-4506 E-mail: rezasehat@yahoo.com
}

Received: March 2, 2012

Accepted: March 19, 2012

Published: June 1, 2012

doi:10.5539/elt.v5n6p9

URL: http://dx.doi.org/10.5539/elt.v5n6p9

\begin{abstract}
Only quite recently has the concept of demotivation (as a partially neglected facet of motivationally-oriented investigations) come to the foreground of attention of researchers and educationalists interested in psycho-affective foundations of learning. Though literature on psycholinguistic underpinnings of learning is laden with varied probes into different pedagogical aspects of motivation, and thereby lack of it, studies directly attending to the notion of demotivation still suffer from a considerable paucity. Thus, faced with the above-said dearth of research on demotivating elements and their repercussions for didactics, the researchers in the current study set out for a partially full-fledged journey through the main underlying reasons for the learners' lack of motivation for learning English as a foreign language, particularly in the context of Iranian high schools. To come up with satisfactory answers to and justifications for the major research questions of the study, which tried to grapple with the demotivational bases of learning among Iranian EFL high school learners, a sample of 165 students from Maragheh (a city in East Azerbaijan, Iran) Nemouneh High School were selected as the participants of the study. The process of data collection was mainly carried out through the administration of a 50-item Likert scale demotivational questionnaire, which mostly centered around the learners' negative experiences of learning English as a foreign language. As a complementary phase to the current study, the English teachers instructing in the said high school were also involved in the course of data collection, through providing answers to an open-ended question concerning their experience of demotivating factors. Successive to the collection of data, several statistical procedures including one-way ANOVAs and chi-squares were run to analyze the learners' responses to the questionnaire items. The findings of the study, in brief, revealed no significant difference among the classes, except for the items related to the effect of teacher's personality and behavior, learners' experience of failure and learners' lack of success. The results also pointed to no significant differences among majors with the exception of the items attending to the effect of teacher's personality and behavior as well as the learners' experience of failure.
\end{abstract}

Keywords: Demotivation, Demotive, Motivation, Iranian EFL learners

"Motivation, like the concept of gravity, is easier to describe (in terms of its outward, observable effects) than it is to define. Of course, this has not stopped people from trying it" (Covington, 1998, p. 1).

\section{Introduction}

\subsection{Overview}

Motivation is a highly complex and multifaceted issue in learning. As Dörnyei (2001a, p. 6) puts it "the term 'motivation' is a convenient way of talking about a concept which is generally seen as a very important human characteristic but which is also immensely complex." In like manner, Wlodkowski (1986, p. 12) contends, "With a hypothetical construct as broad and complex as motivation, there is always room for controversy and argumentation." A thorough definition of motivation by Dörnyei and Ottó (1998, p. 65) came to recognize many of the advancements in the understanding of motivation. According to them motivation refers to, "the dynamically 
changing cumulative arousal in a person that initiates, directs, coordinates, amplifies, terminates, and evaluates the cognitive and motor processes whereby initial wishes and desires are selected, prioritized, operationalised, and (successfully or unsuccessfully) acted out."

Even in language learning there are a lot of studies which indicate the effect of motivation on the outcome of learning. Research results indicate that motivation is one of the main determining factors in an individual's success in developing a second (L2) or foreign language (FL). However, motivation is not the only factor involved in learning other languages. There are other factors which act on the opposite direction of motivation and impede students from being motivated to learn English and participate in learning activities. These factors are de-motives which lead to de-motivation. It means contrary to positive forces that facilitate in sustaining motivation, de-motivating forces reduce motivation during action. Falout and Maruyama (2004) believe if motivation pushes learning for life, de-motivation cuts learning short.

As English has become more and more important as an international language in most countries around the world, large numbers of students are being required to learn it through compulsory programs in schools and universities. It is supposed that de-motivation might be a factor that would account for at least some of the causes of failure in language learning. Education literature recognizes that students often need to unlearn false understandings before they can acquire new understandings (Gardner, 1985; Gardner and Lambert, 1972). Similarly, experience is demonstrating that students cannot be motivated to learn while retaining strong reasons for de-motivation against learning. Before motivating reluctant learners, it is first necessary to know what factors cause de-motivation and then remove the de-motivating factors and perceptions that prevent engagement in learning or willingness to be motivated.

\subsection{Statement of the Problem}

Being faced with the bitter fact that most EFL learners in Iranian public high schools don't follow the taught English coursebooks eagerly and merely participate in compulsory classes in order to pass the final exams, the researchers in the current study were coaxed to embark on a full-fledged probe into the reasons underlying this phenomenon. Iran is among the countries for which English is regarded as a foreign language which is taught to learners only in the formal context of classes and hence very few occasions might be encountered where learners find the opportunity to converse with the natives of English in real-life circumstances. Furthermore, it is mostly the case that students form negative attitudes towards learning English partly because of the learning difficulties that stem from non-contextualized manner in which the courses are presented. Accordingly, it is not uncommon to encounter a considerable number of de-motivated learners who abandon learning English mostly because they are faced with a multitude of demotivating factors mainly emanating from their lack of awareness as to the privileges acquaintance with English might bring to them.

In such a state of affairs, then, it follows that in spite of their adequate level of intrinsic motivation, these students either mentally withdraw or look for strategies to pass the required exams with a minimum of effort, look at the course just as a subject matter to be passed and do not really grasp its importance as a means of communication with which they can adapt themselves to new improvements in science and technology. Though formal exposure to English in Iranian high schools endures for seven years (three years in guidance school, three years in high school and 1 year in pre-university level), the majority of learners who graduate with this system are incapable of applying the taught material for negotiation of meaning in real-life settings. As a consequence, most students come to the point where they feel they have lost their interest in learning English, that is, they have become de-motivated.

Thus far, it must have been understood that the main preoccupation of the researchers in the present study is nothing but addressing the issue of demotivation in Iranian high schools and thereby setting out for a campaign to pinpoint the main reasons underlying this quandary. In so doing, the researchers strive to come up with a sort of modus operandi to tackle this prevalent problem. Put in simpler words, the current study aims to probe the main demotivating factors and their respective importance in Iranian context of language learning, particularly in the high schools. Of special importance in this regard is the hunt for the possible difference between different grades and majors in terms of the role of different de-motivators.

\subsection{Significance of the Study}

While a plethora of studies, to date, have strived to investigate the concept of motivation in Second Language Acquisition (SLA) from a multitude of varied perspectives, there is still a scant body of research attending to the paramount notion of de-motivation in both foreign and second language learning contexts. Moreover, the effect of de-motivation on the acquisition and learning of foreign languages in Iran has rarely been discussed. Thus, in an attempt to somehow compensate for the skimpy heed given to this focal area, the major concern and preoccupation of the researchers in the current study centered around pinning down the major de-motivating factors standing on the 
way of Iranian EFL high school learners.

On account of the foregoing discussion, the present study is thought to be of particular interest to language educators and students because of the potentially negative repercussions de-motivation produces in all educational settings. This study is also significant with respect to its implications for disparate facets of foreign language pedagogy, in that investigation of de-motives will broaden our insights to make learning environment positively motivated. In line with Muhonen (2004), the darker side of motivation or de-motivation has been, to a great extent, ignored in research on L2 without considering the fact that it has direct educational implications. In other words, in addition to knowing what motivates a learner, being aware of the hazards that undermine motivation is essential for both teachers and learners.

\subsection{Research Questions}

Though a sizable body of research in the realm of EFL/ESL has dealt with learner motivation and its ramifications for language learning, the concept of demotivation and its implications for learning is still among the notions to which only scant attention has been given on the part of educationalists, practitioners and researchers. What further complicates the task of dealing with demotives is the postulation that these better-called hindering factors are different in terms of their levels of influence on individuals, so that some types of de-motives might have a permanent effect on students, while others are likely to be easier to overcome once the detrimental influence has ceased to exist.

The principal focus of the present study was, therefore, on the role of de-motivation in students' learning of English as a foreign language. Thus, to set the foundation for an in-depth investigation of demotives, the following research questions were formulated:

1- What are the factors that learners of English in Iran perceive as de-motivating while learning English?

2- What is the frequency and order of importance of the de-motivating factors?

3- Are there any significant differences with regard to the effect of different de-motives in different classes?

4- Are there significant differences with regard to the effect of different de-motives in different majors?

\section{Literature Review}

\subsection{Demotivation}

Past motivation research has mainly concentrated on the positive motivational influences. According to Dörnyei $(2001 \mathrm{a} / \mathrm{b})$, in addition to positive influences there are, however, negative effects that de-energize action. This darker side of motivation, that is de-motivation, has been found to play a crucial role in the learning process, yet it has been neglected as a research topic until fairly recently.

In a study on de-motivation Gorham and Christophel (1992) investigated factors that make college students lose their motivation. Investigation was done by means of an open-ended question that read: "What things decrease your motivation to try hard to do your best in class?" Three main categories were found which are as follows: context de-motives (factors likely to be regarded as antecedent to the teacher's influence), structure/format de-motives (factors over which the teacher is likely to have some degree of influence, if not complete control), and teacher behaviors (factors likely to be perceived as under the teacher's direct control). On the whole, teacher-related factors accounted for $79 \%$ of all responses.

Gary Chambers (1998/1999) conducted a study to find out what goes on inside the heads of students who are de-motivated. Chambers visited four schools in Leeds, UK, and administered a questionnaire to 191 students enrolled in eight classes. Seven teachers also filled in a questionnaire. Teachers portrayed de-motivated students' characteristics as follows:

- makes no effort to learn; shows no interest; demonstrates poor concentration; produces little or no homework; fails to bring, or claims to have lost materials;

- lacks a belief in own capabilities;

- gives negative or nil response to praise;

- is unwilling to cooperate, distracts other students, throws things, shouts out.

Interestingly enough, teachers did not include themselves. On the other hand, the students' responses were different, and some of them blamed their teachers for

- going on and on without realizing that they have lost everybody;

- not giving clear enough instructions; 
- using inferior equipment;

- not giving sufficient explanations;

- criticizing students;

- shouting at them when they don't understand;

- using old-fashioned teaching materials, etc.

In a study on de-motivation aimed at examining whether teachers' perceptions of what de-motivates students were similar to those found in students' report, Gorham and Millette (1997) made use of an open-ended question that read 'What do you perceive decreases students' motivation to try to do their best in class and to achieve their instructional goals?' The results showed that teachers and students agreed on the central de-motivating factors. The high frequency categories were similar in both groups and also the order of frequency was more similar than different. In spite of similarities, it was found that teachers attributed student de-motivation to students' performance and lack of needed skills, whereas students themselves attributed their de-motivation to teachers' behavior and personality.

In another investigation conducted by Ushioda (1996) among 20 university-level learners of French at Trinity College, Dublin in Ireland, the participants were asked to identify what they found to be de-motivating in their L2-related learning experience without specifying any prompts. Her findings were not unlike the conclusions arrived at in the previous studies, that is, de-motives were related to negative aspects of the institutionalized learning context such as particular teaching methods and learning tasks.

Oxford (1998) conducted a study on 250 American high school and university students to get information specifically on de-motivating factors. They were asked to write about their learning experiences over a period of five years by using prompts such as 'Describe a situation in which you experienced conflict with a teacher' and 'Talk about a classroom in which you felt uncomfortable'. Four broad themes emerged through content analysis of the data. The first one of these was the teacher's personal relationship with the students. The teacher's attitude towards the course or the material made up the second theme. The third theme consisted of style conflicts between teachers and students. The nature of the classroom activities made up the fourth theme.

The study by Dörnyei (1998) differed from the studies presented above in the sense that it concentrated specifically on pupils who had been identified as being de-motivated. Dörnyei identified the following de-motivating factors:

1. The teacher (personality, commitment, competence, teaching method);

2. Inadequate school facilities (group is too big or not the right level, frequent change of teachers);

3. Reduced self-confidence (experience of failure or lack of success);

4. Negative attitude towards the L2;

5. Compulsory nature of L2 study;

6. Interference of another foreign language being studied;

7. Negative attitude towards L2 community;

8. Attitudes of group members;

9. Course book

In Finland, Muhonen (2004) conducted a study to find out factors that cause pupils to lose their motivation for learning English. He asked 91 ninth-grade pupils in a comprehensive school in Jyvaskyla to write about issues that had had a negative influence on their motivation to learn English. On the basis of qualitative content analysis, several de-motives emerged from the data. First theme, i.e. teacher related de-motives, subsumed three sub-categories: teaching method, lack of competence, and personality. Second theme in the order of importance was learning material and especially the textbooks were criticized for having boring content or exercises. Third theme, de-motivating factors within learners themselves were labeled as learner characteristics, and they were found to have effects on motivation, in that lowered confidence in pupils' language skills and lack of skills were said to have de-motivating effect as the pupils were left behind in the class. The fourth theme, i.e. school environment included three types of problems: inappropriate scheduling of English classes, changes in the teachers (where a good teacher had been replaced by a not-so-good one), and physical properties of the classroom. Learners' attitudes toward the English language were found to be the fifth and last theme causing students to lose their motivation to learn English.

Trang and Baldauf (2007) conducted a study to find out factors that caused students to lose their interest in learning. De-motives received from data were classified into two broad groups: internal attributions and external attributions. 
Internal de-motives included students' attitudes toward English, their experiences of failure or lack of success, and incidents related to their self-esteem; the external attributions consisted of teacher-related factors, the learning environment, and other external factors. Students attributed $36 \%$ of de-motives to internal attributions and $64 \%$ of de-motives were ascribed to external attributions. In external attributions teacher related factors were the main source of de-motives whereas among internal attributions, students' experiences of failure or lack of success were the main sources of de-motivation.

De-motives among Japanese high school students were explored in a study by Sakai and Kikuchi (2009) through a 35-item questionnaire. They collected data from 656 students by making use of a questionnaire consisting of 35 5-point Likert type questions about de-motivation, which were designed to measure six constructs raised in the previous studies: teachers, characteristics of classes, experiences of failure, class environment, class materials, and lack of interest. The study revealed that in contrast to most of the previous studies, factors related to teacher were not found to have a very strong de-motivating influence compared to learning contents and materials or test scores which were found to be the two most salient de-motives among participants. In addition, lack of intrinsic motivation was found to be as salient as a teacher's competence and teaching styles which suggests that internal forces have to also be taken into account when discussing de-motivation. Although insufficient school facilities were mentioned by some of the participants, they were not found as de-motivating factors.

Finally, according to a study by Hirvonen (2010) on immigrant pupils, two broad categories of de-motives emerged. They were classified as external and internal de-motives. The external de-motives fell under four themes: the teacher, learning material and course contents, learning environment and simultaneous learning of many languages. The issues relevant to the first theme, teacher, were the widest and the ones pertaining to the fourth theme, simultaneous learning of many languages, could have been expected to be the most influential problem for immigrant pupils, but it was not mentioned by all of the pupils. Internal themes, which were influential in the English learning experiences, were experience of failure, lack of success and attitudes toward English. Learners' experience of failure and lack of success in learning English had made them perceive it as an impossible task. Learners' attitudes toward the English language and perception of pronunciation or grammar as difficult had de-motivated some participants.

\section{Method}

\subsection{Participants}

One hundred and sixty five subjects from Nemoneh high school in Maragheh (a fairly large city in East Azerbaijan, Iran) participated in the current study. The participants fell within one of the following two categories: 1) EFL learners, 2) highly experienced EFL teachers. The age of the learners taking part in the present study ranged from sixteen to eighteen and they were only males. In terms of the grades they were studying in, the first-graders had been learning for at least four years, second-grade students for five years and third-graders for six years. Furthermore, the teaching experience of teachers ranged from ten to thirty years. The rationale behind including them in this study was to gain more relevant and rich data as a result of their teaching experience. The mother tongue of all the participants was Turkish. The chosen sample enjoyed a good level of variability, in that the participants came from a range of different cities in East Azerbaijan, including Maragheh, Malekan, Kharaju and Leilan.

\subsection{Instruments}

The main instrument utilized in the present study was the EFL De-motivational Questionnaire, which consisted of fifty Likert-type items, and was adapted from the previous body of research conducted on de-motivation, particularly the ones carried out by Sakai and Kikuchi (2009), Warrington (2005) and Muhonen (2004). The second questionnaire used in the current survey comprised of an open-ended question in which the teachers were required to portray the characteristics of de-motivated students and to mention what factors contribute to de-motivation of students. The learners' participation in the study was done on a voluntary basis and the learners had been ensured that their answers would be kept confidential. Students were required to complete the questionnaire within 20-25 minutes. The questionnaire items had already been translated to Persian (the National language in Iran) to ease the suitable process of responding. The reliability coefficients for different subsections of the translated questionnaire are reported in Table 1. All students appeared to have no trouble in completing the questionnaire in the required time.

\subsection{Data Collection and Analysis}

As one of the researchers himself was a teacher in the school where data collection was carried out, access to the subjects was facilitated to a great extent. During the initial contact with the participants, the nature of the study was explained: that it was voluntary, and the information gained from them would be kept strictly confidential. The students were informed that the survey would have no effect on their grade. All the students in six classes in 
Nemoneh high school (two classes of freshmen with no major specification, one second-grade class majoring in experimental sciences and three third-grade classes, two of which had math as their field of study and one studying experimental sciences) were given The EFL De-motivational Questionnaire, which comprised of statements relevant to the students' negative or demotivating experiences. The questionnaire was adapted based on two broad sources of de-motivation, i.e. external and internal, proposed by Sakai and Kikuchi (2009) and also statements mentioned by students in the study carried out by Jenni muhonen (2004). To look closely into factors that cause student to lose their motivation, another (open-ended) questionnaire was given to the teachers in the same school to portray the characteristics of students who feel de-motivated. A demographic questionnaire was also administered to the teachers to tap information regarding issues such as teaching experience, type of school in which they taught (public or private), etc. Successive to data collection phase, the gained data were fed into SPSS, and analyzed mainly through chi-square and one-way ANOVA.

\section{Results}

\subsection{Rank Order of Sources of De-motivation among EFL Learners}

The main sources of de-motivation among EFL learners involved in the current study according to Tables 2 and 3 are as follows: learning environment (Q3) with mean rank of 6.07, simultaneous learning of other languages (Q4) with mean rank of 5.91, learning material and course content (Q2) with mean rank of 5.62, teaching method (Q1A) with mean rank of 5.49, experience of failure (EX2) with mean rank of 5.22, lack of success (EX3) with mean rank of 5.17, teacher's personality and behavior (Q1B) with mean rank of 4.44, learners' characteristics (EX1) with mean rank of 4.07, and attitude (EX4) with mean rank of 3.02.

In what follows the participants' attitudes regarding different de-motivating factors are presented by disclosing the relevant frequency distributions and percentages for each of the nine separate factors encompassed in the questionnaire.

\subsubsection{Teaching Method (Q1A)}

As Table 4 and Figure 1 show, the percentage of students who believed that teaching method has little effect on de-motivation was 13.9. Furthermore, $\% 81.8$ thought it had moderate effect and $\% 4.2$ believed it had a great effect.

\subsubsection{Teacher Personality and Behavior (Q1B)}

In line with the information in Table 5 and Figure 2, the percentage of students who believed teacher personality and behavior has little effect on de-motivation was 39.4. Furthermore, $\% 53.3$ thought it had moderate effect and \% 7.3 believed it had a great effect.

\subsubsection{Learning Material and Course Content (Q2)}

Based on the data in Table 6 and Figure 3, the percentage of students who believed learning material and course content has little effect on de-motivation was 21.8 . Moreover, $\% 71.5$ thought it had moderate effect and \% 6.7 believed it had a great effect.

\subsubsection{Learning Environment (Q3)}

As the findings in Table 7 and Figure 4 reveal the percentage of students who believed learning environment has little effect on de-motivation was 15.2. In addition, $\% 67.3$ thought it had moderate effect and $\% 17.6$ believed it had a great effect.

\subsubsection{Simultaneous Learning of Other Languages (Q4)}

According to what is presented in Table 8 and Figure 5, the percentage of students who believed simultaneous learning of other languages has little effect on de-motivation was 34.5. Besides, \% 21.2 thought it had moderate effect and $\% 44.2$ believed it had a great effect.

\subsubsection{Learner Characteristics}

As Table 9 and Figure 6 depict, the percentage of students who believed learner characteristics has little effect on de-motivation was 49.7. Additionally, $\% 47.9$ thought it had moderate effect and $\% 2.4$ believed it had a great effect.

\subsubsection{Learners' Experience of Failure (EX2)}

Table 10 and Figure 7 are indicative of the fact that the percentage of students who believed learners' experience of failure has little effect on de-motivation was 40.6. Furthermore, \% 35.2 thought it had moderate effect and \% 24.2 believed it had a great effect.

\subsubsection{Learners' Lack of Success (EX3)}

Drawing on the data in Table 11 and Figure 8 it can be concluded that the percentage of students who believed 
learners' lack of success has little effect on de-motivation was 32.7. Further, $\% 55.2$ thought it had moderate effect and $\% 12.1$ believed it had a great effect.

\subsubsection{Learners' Attitude (EX4)}

Finally, as Table 12 and Figure 9 illustrate the percentage of students who believed learners' Attitude has little effect on de-motivation was 65.5. Also, \% 33.9 thought it had moderate effect and $\% 0.6$ believed it had a great effect.

\subsection{Comparison of the Effects of the Sources of De-motivation among Students}

\subsubsection{Teaching Method (Q1A)}

Table 13 (Chi-Square Test Frequencies) and Table 14 (Chi-Square test Results) show that the number of students who believed that teaching method (Q1A) has little effect on de-motivation was 23 , students who believed that it has average effect were135, and those who believed that it has a great effect on de-motivation of students were only 7 . Also, as the chi-square results reveal $\left(\mathrm{x}^{2}=176.873, p=0.000\right)$, the effect of teaching method among the learners is significant at .05 .

\subsubsection{Teacher's Personality and Behavior (Q1B)}

As Tables 15 and 16 represent, the number of students who believed that teacher's personality and behavior (Q1B) has little effect on de-motivation was 65 , students who believed that it has average effect were 88 , and those who believed that it has a great effect on de-motivation of students were only 12. Moreover, as the chi-square results reveal $\left(x^{2}=55.236, p=0.000\right)$, the effect of teacher's personality and behavior among the learners is significant at .05 .

\subsubsection{Learning Material and Course Content (Q2)}

In line with the findings reported in Tables 17 and 18, the number of students who believed that learning material and course content (Q2) has little effect on de-motivation was 36, students who believed that it has average effect were 118, and those who believed that it has a great effect on de-motivation of students were only 11. Moreover, as the chi-square results reveal $\left(x^{2}=113.927, p=0.000\right)$, the effect of learning material and course content among the learners is significant at .05 .

\subsubsection{Learning Environment (Q3)}

According to the data presented in Tables 19 and 20, the number of students who believed that learning environment has little effect on de-motivation was 25 , students who believed that it has average effect were 111 , and those who believed that it has a great effect on de-motivation of students were 29. Furthermore, as the chi-square results reveal $\left(\mathrm{x}^{2}=85.673, p=0.000\right)$, the effect of learning material and course content among the learners is significant at 05 .

\subsubsection{Simultaneous Learning of Many Languages (Q4)}

Based on what is depicted in Tables 21 and 22, the number of students who believed that simultaneous learning of other languages has little effect on de-motivation was 57, students who believed that it has average effect were 35 and those who believed that it has a great effect on de-motivation of students were 73 . Additionally, as the chi-square results reveal $\left(\mathrm{x}^{2}=13.236, p=0.001\right)$, the effect of learning material and course content among the learners is significant at .05 .

\subsubsection{Learner Characteristics (EX1)}

Drawing on the data in Tables 23 and 24, the number of students who believed that learner characteristics have little effect on de-motivation was 82 , students who believed that it has average effect were 79 , and those who believed that it has a great effect on de-motivation of students were merely 4 . In addition, as the chi-square results reveal $\left(\mathrm{x}^{2}\right.$ $=71.018, p=0.000$ ), the effect of learner characteristics among the learners is significant at .05 .

\subsubsection{Learners' Experience of Failure (EX2)}

As Tables 25 and 26 reveal, the number of students who believed that learners' experience of failure has little effect on de-motivation was 67 , students who believed that it has average effect were 58 , and those who believed that it has a great effect on de-motivation of students were merely 40 . In addition, as the chi-square results reveal $\left(\mathrm{x}^{2}=\right.$ $6.873, p=0.032$ ), the effect of learners' experience of failure among the learners is significant at .05 .

\subsubsection{Learners' Lack of Success (EX3)}

As Tables 27 and 28 illustrate, the number of students who believed that learners' lack of success has little effect on de-motivation was 54, students who believed that it has average effect were 91, and those who believed that it has a great effect on de-motivation of students were 20 . In addition, as the chi-square results reveal $\left(\mathrm{x}^{2}=45.855, p=\right.$ 0.000 ), the effect of learners' lack of success among the learners is significant at .05 . 


\subsubsection{Learners' Attitudes (EX4)}

According to what is reported in Tables 29 and 30, the number of students who believed that learners' attitudes has little effect on de-motivation was 108 , and the students who believed that it has average effect were 56. Yet, only one student believed that it has a great effect on de-motivation of students. Moreover, as the chi-square results reveal $\left(x^{2}=104.109, p=0.000\right)$, the effect of learners' attitudes among the learners is significant at .05 .

\subsection{Comparison of De-motives on the Basis of Students' Classes}

\subsubsection{Teaching Method (Q1A)}

Tables 31 and 32 show the effect of teaching method as a de-motivating factor among classes as follows: third grade math class1 $(\mathrm{M}=1.95, \mathrm{SD}=.57)$, third grade sciences class $(\mathrm{M}=2.000, \mathrm{SD}=.25)$, first grade $1(\mathrm{M}=1.86$, $\mathrm{SD}$ $=.345)$, third grade math class $2(\mathrm{M}=1.88, \mathrm{SD}=.331)$, second grade $3(\mathrm{M}=1.96, \mathrm{SD}=.428)$, and first grade $2(\mathrm{M}$ $=1.75, \mathrm{SD}=.585)$. A one way analysis of variance indicated that there was no significant difference $(\mathrm{F}=1.365, p$ $=.24$ ) regarding the effect of teacher's teaching method on de-motivation of students in different classes due to the fact that the level of significance was more than .05 .

\subsubsection{Teacher's Personality and Behavior (Q1B)}

Tables 33 and 34 show the effect of teacher's personality and behavior as a de-motivating factor among classes as follows: third grade math class $1(\mathrm{M}=182, \mathrm{SD}=.57)$, third grade sciences class $(\mathrm{M}=2.19, \mathrm{SD}=.4)$, first grade $1(\mathrm{M}=1.33, \mathrm{SD}=.6)$, third grade math class $2(\mathrm{M}=1.76, \mathrm{SD}=.43)$, second grade sciences $3(\mathrm{M}=1.71, \mathrm{SD}=.59)$, and first grade $2(\mathrm{M}=1.25, \mathrm{SD}=.44)$. A one way analysis of variance indicated that there was a significant difference $(\mathrm{F}=13.252, p=.000)$ regarding the effect of teacher's personality and behavior on de-motivation of students in different classes owing to the fact that the level of significance was less than .05 .

\subsubsection{Learning Material and Course Content (Q2)}

Tables 35 and 36 depict the effect of learning material and course content as a de-motivating factor among classes as follows: third grade math class $1(\mathrm{M}=1.78, \mathrm{SD}=.421)$, third grade sciences class $(\mathrm{M}=1.976, \mathrm{SD}=.546)$, first grade $1(\mathrm{M}=1.80, \mathrm{SD}=.550)$, third grade math class $2(\mathrm{M}=1.80, \mathrm{SD}=.500)$, second grade sciences $3(\mathrm{M}=1.78$, $\mathrm{SD}=.568)$, and first grade $2(\mathrm{M}=1.92, \mathrm{SD}=.465)$. A one way analysis of variance indicated that there was no significant difference $(\mathrm{F}=.722, p=.608)$ regarding the effect of learning material and course content on de-motivation of students in different classes due to the fact that the level of significance was more than .05 .

\subsubsection{Learning Environment (Q3)}

Tables 37 and 38 demonstrate the effect of learning environment as a de-motivating factor among classes as follows: third grade math class $1(\mathrm{M}=1.869, \mathrm{SD}=.694)$, third grade sciences class $(\mathrm{M}=2.064, \mathrm{SD}=.512)$, first grade $1(\mathrm{M}$ $=2.10, \mathrm{SD}=.547)$, third grade math class $2(\mathrm{M}=2.000, \mathrm{SD}=.288)$, second grade sciences $3(\mathrm{M}=2.142, \mathrm{SD}$ $=.590)$, and first grade $2(\mathrm{M}=1.928, \mathrm{SD}=.716)$. A one way analysis of variance indicated that there was no significant difference $(\mathrm{F}=.871, p=.502)$ with regard to the effect of learning environment on de-motivation of students in different classes due to the fact that the level of significance was more than .05 .

\subsubsection{Simultaneous Learning of Many Languages (Q4)}

Tables 39 and 40 illustrate the effect of simultaneous learning of many languages as a de-motivating factor among classes as follows: third grade math class $1(\mathrm{M}=2.391, \mathrm{SD}=.891)$, third grade sciences class $(\mathrm{M}=2.129, \mathrm{SD}$ $=.921)$, first grade $1(\mathrm{M}=2.233, \mathrm{SD}=.817)$, third grade math class $2(\mathrm{M}=1.720, \mathrm{SD}=.842)$, second grade sciences $3(\mathrm{M}=2.035, \mathrm{SD}=.922)$, and first grade $2(\mathrm{M}=2.0714, \mathrm{SD}=.875)$. A one way analysis of variance indicated that there was no significant difference $(\mathrm{F}=1.629, p=.155)$ as to the effect of simultaneous learning of many languages on de-motivation of students in different classes due to the fact that the level of significance was more than .05 .

\subsubsection{Learner Characteristics (EX1)}

Tables 41 and 42 show the effect of learner characteristics as a de-motivating factor among classes as follows: third grade math class $1(\mathrm{M}=1.478, \mathrm{SD}=.593)$, third grade sciences class $(\mathrm{M}=1.677, \mathrm{SD}=.540)$, first grade $1(\mathrm{M}=1.5$, $\mathrm{SD}=.572)$, third grade math class $2(\mathrm{M}=1.6, \mathrm{SD}=.577)$, second grade science $3(\mathrm{M}=1.357, \mathrm{SD}=.487)$, and first grade $2(\mathrm{M}=1.53, \mathrm{SD}=.547)$. A one way analysis of variance indicated that there was no significant difference $(\mathrm{F}=$ $1.155, p=.334)$ as to the effect of learner characteristics on de-motivation of students in different classes due to the fact that the level of significance was more than .05 .

\subsubsection{Learners' Experience of Failure (EX2)}

Tables 43 and 44 demonstrate the effect of learners' experience of failure as a de-motivating factor among classes as 
follows: third grade math class $1(\mathrm{M}=1.956, \mathrm{SD}=.705)$, third grade sciences class $(\mathrm{M}=2.387, \mathrm{SD}=.715)$, first grade $1(\mathrm{M}=1.666, \mathrm{SD}=.711)$, third grade math class $2(\mathrm{M}=1.68, \mathrm{SD}=.802)$, second grade sciences $3(\mathrm{M}=1.821$, $\mathrm{SD}=.772)$, and first grade $2(\mathrm{M}=1.464, \mathrm{SD}=.744)$. A one way analysis of variance indicated that there was a significant difference $(\mathrm{F}=5.486, p=.000)$ regarding the effect of learners' experience of failure on de-motivation of students in different classes due to the fact that the level of significance was less than 05 .

\subsubsection{Learners' Lack of Success (EX3)}

Tables 45 and 46 show the effect of learners' lack of success as a de-motivating factor among classes as follows: third grade math class $1(\mathrm{M}=1.608, \mathrm{SD}=.499)$, third grade sciences class $(\mathrm{M}=2.193, \mathrm{SD}=.703)$, first grade $1(\mathrm{M}$ $=1.73, \mathrm{SD}=.639)$, third grade math class $2(\mathrm{M}=1.76, \mathrm{SD}=.663)$, second grade sciences $3(\mathrm{M}=1.71, \mathrm{SD}=.534)$, and first grade $2(\mathrm{M}=1.678, \mathrm{SD}=.611)$. A one way analysis of variance indicated that there was a significant difference $(\mathrm{F}=3.376, p=.006)$ as to the effect of learners' experience of failure on de-motivation of students in different classes due to the fact that the level of significance was less than .05 .

\subsubsection{Learners' Attitudes (EX4)}

Finally, Tables 47 and 48 demonstrate the effect of learners' attitudes as a de-motivating factor among classes as follows: third grade math class $1(\mathrm{M}=1.391, \mathrm{SD}=.499)$, third grade sciences class $(\mathrm{M}=1.419, \mathrm{SD}=.501)$, first grade $1(\mathrm{M}=1.233, \mathrm{SD}=.430)$, third grade math class $2(\mathrm{M}=1.32, \mathrm{SD}=.476)$, second grade sciences $3(\mathrm{M}=$ $1.428, \mathrm{SD}=.503)$, and first grade $2(\mathrm{M}=1.32, \mathrm{SD}=.547)$. A one way analysis of variance indicated that there was no significant difference $(\mathrm{F}=.668, p=.649)$ regarding the effect of learners' attitude on de-motivation of students in different classes due to the fact that the level of significance was more than .05 .

\subsection{Comparison of De-motives on the Basis of Students' Major}

\subsubsection{Teaching Method (Q1A)}

Tables 49 and 50 show the effect of teaching method as a de-motivating factor among majors as follows: first graders with no major specification $(\mathrm{M}=1.810, \mathrm{SD}=.475)$, math students $(\mathrm{M}=1.916, \mathrm{SD}=.403)$, and experimental sciences students $(\mathrm{M}=1.983, \mathrm{SD}=.346)$. A one way analysis of variance indicated that there was no significant difference ( $\mathrm{F}=2.601, p=.077)$ as to the effect of teacher's teaching method on de-motivation of students in different majors due to the fact that the level of significance was more than .05 .

\subsubsection{Teacher's Personality and Behavior (Q1B)}

Tables 51 and 52 show the effect of teacher's personality and behavior as a de-motivating factor among majors as follows: first graders with no major specification $(\mathrm{M}=1.293, \mathrm{SD}=.530)$, math students $(\mathrm{M}=1.791, \mathrm{SD}=.503)$, and experimental sciences students $(\mathrm{M}=1.966, \mathrm{SD}=.556)$. A one way analysis of variance indicated that there was a significant difference $(\mathrm{F}=24.918, p=.000)$ regarding the effect of teacher's personality and behavior on de-motivation of students in different majors owing to the fact that the level of significance was less than .05 .

\subsubsection{Learning Material and Course Content (Q2)}

Tables 53 and 54 illustrate the effect of learning material and course content as a de-motivating factor among majors as follows: first graders with no major specification $(\mathrm{M}=1.862, \mathrm{SD}=.511)$, math students $(\mathrm{M}=1.791, \mathrm{SD}=.459)$, and experimental sciences students $(\mathrm{M}=1.881, \mathrm{SD}=.559)$. A one way analysis of variance indicated that there was no significant difference $(\mathrm{F}=.432, p=.650)$ as to the effect of learning material and course content on de-motivation of students in different majors due to the fact that the level of significance was more than .05 .

\subsubsection{Learning Environment (Q3)}

Tables 55 and 56 demonstrate the effect of learning environment as a de-motivating factor among majors as follows: first graders with no major specification $(\mathrm{M}=2.017, \mathrm{SD}=.634)$, math students $(\mathrm{M}=1.937, \mathrm{SD}=.552)$, and experimental sciences students $(\mathrm{M}=2.101, \mathrm{SD}=.547)$. A one way analysis of variance indicated that there was no significant difference $(\mathrm{F}=1.093, p=.338)$ with regard to the effect of learning environment on de-motivation of students in different majors owing to the fact that the level of significance was more than .05.

\subsubsection{Simultaneous Learning of Many Languages (Q4)}

Tables 57 and 58 show the effect of simultaneous learning of many languages as a de-motivating factor among majors as follows: first graders with no major specification $(\mathrm{M}=2.155, \mathrm{SD}=.833)$, math students $(\mathrm{M}=2.041$, $\mathrm{SD}$ $=.921)$, and experimental sciences students $(\mathrm{M}=2.084, \mathrm{SD}=.915)$. A one way analysis of variance indicated that there was no significant difference $(\mathrm{F}=.223, p=.801)$ as to the effect of simultaneous learning of many languages on de-motivation of students in different majors due to the fact that the level of significance was more than .05 . 


\subsubsection{Learner Characteristics (EX1)}

Tables 59 and 60 show the effect of learner characteristics as a de-motivating factor among majors as follows: first graders with no major specification $(\mathrm{M}=1.517, \mathrm{SD}=.537)$, math students $(\mathrm{M}=1.541, \mathrm{SD}=.581)$, and experimental sciences students $(\mathrm{M}=2.084, \mathrm{SD}=.536)$. A one way analysis of variance indicated that there was no significant difference $(\mathrm{F}=.026, p=.974)$ regarding the effect of learner characteristics on de-motivation of students in different majors, for the level of significance was more than .05 .

\subsubsection{Learners' Experience of Failure (EX2)}

Tables 61 and 62 show the effect of learners' experience of failure as a de-motivating factor among classes as follows: first graders with no major specification $(\mathrm{M}=1.569, \mathrm{SD}=.728)$, math students $(\mathrm{M}=1.812, \mathrm{SD}=.762)$, and experimental sciences students $(\mathrm{M}=2.118, \mathrm{SD}=.789)$. A one way analysis of variance indicated that there was a significant difference $(\mathrm{F}=.7 .672, p=.001)$ as to the effect of learners' experience of failure on de-motivation of students in different majors, as the level of significance was less than .05 .

\subsubsection{Learners' Lack of Success (EX3)}

Tables 63 and 64 represent the effect of learners' lack of success as a de-motivating factor among majors as follows: first graders with no major specification $(\mathrm{M}=1.706, \mathrm{SD}=.621)$, math students $(\mathrm{M}=1.687, \mathrm{SD}=.589)$, and experimental sciences students $(\mathrm{M}=1.966, \mathrm{SD}=.668)$. A one way analysis of variance indicated that there was no significant difference $(\mathrm{F}=3.444, p=.034)$ with regard to the effect of learners' experience of failure on de-motivation of students in different because the level of significance was more than .05 .

\subsubsection{Learners' Attitude (EX4)}

Finally, Tables 65 and 66 depict the effect of learners' attitude as a de-motivating factor among majors as follows: first graders with no major specification $(\mathrm{M}=1.275, \mathrm{SD}=.488)$, math students $(\mathrm{M}=1.354, \mathrm{SD}=.483)$, and experimental sciences students $(\mathrm{M}=1.423, \mathrm{SD}=.498)$. A one way analysis of variance indicated that there was no significant difference ( $\mathrm{F}=1.330, p=.267)$ as to the effect of learners' attitude on de-motivation of students in different classes owing to the fact that the level of significance was more than .05 .

\subsection{Teachers' Perceptions of What Affects Student Motivation}

Teachers were asked to provide answers (in written form) to an open-ended question that read "What do you perceive decreases students' motivation to try to do their best in class and achieve their instructional goals?" The following factors were pointed out as the most influential in bringing about the de-motivation of learners: high amount of unemployment in society, teacher's economical problems, too much work load, teacher's personality (e.g. impatience over students' mistakes and criticizing them too much), exams and textbooks.

\section{Discussion}

The current study intended to investigate the sources of de-motivation among high school students. The researchers originally assumed that teacher personality and behavior, teaching method, learning material and content, learning environment (compulsory nature of learning English is included in learning environment), simultaneous learning of other languages, attitudes toward English, learners' experience of failure, learners' lack of success and learner characteristics were the sources of de-motivation. In general, as the results revealed, motivation was found to have been affected by internal and external de-motives. Not all factors in this study were found to negatively influence EFL learning on the whole. In regard to the research hypotheses, the findings revealed that teacher personality and behavior, teacher's teaching method, simultaneous learning of many languages, attitudes toward English, learners' experience of failure, learners' lack of success and learners' characteristics were accepted to have affected students' motivation, whereas the effects of learning material and course content and learning environment on the students' motivation were rejected. One possible explanation is that learning material, course content and learning environment are out of our control and hence the same for all the students.

The research findings revealed the teacher was not the dominant de-motivating factor. Most respondents had positive perceptions of their teacher's personality and teaching method, suggesting that poor teacher behaviors and teaching methods are not a substantial problem for learners. In contrast, learning environment (improper class programming and lack of teaching aids and equipments in teaching) was found to be in the first place in terms of de-motivating factors.

Furthermore, the findings pointed toward significant class differences in case of teacher's personality and behavior, learners' experience of failure and learners' lack of success as de-motivational factors for learning English language. One reason could be that students' experience of failure and lack of success are different from one another and due to the fact that different teachers were teaching in different classes, they are expected to have had different effects in 
different classes. Nonetheless, the study didn't come up with any significant class differences in terms of learning material and course content, learning environment, simultaneous learning of many languages, learner characteristics and learners' attitude. The researchers are not sure how to explain these results because they expected a significant difference between six classes.

While teacher's personality and behavior and learners' experience of failure yielded significant differences between majors (first grade, math and science), learners' lack of success, learning material and course content, learning environment, simultaneous learning of many languages, learner characteristics and learners' attitude yielded no significant differences between majors. Once again no firm resolution was attained with regard to these results because the researchers expected a significant difference between majors. It is possible that differences would have been greater if more classes from different schools had been included in the study.

\section{Conclusion}

The study at hand aimed at finding the common factors that are perceived as de-motivating by EFL learners of Iran especially in Maragheh. This study succeeded in shedding light on how Maragheh Nemoneh high school pupils experience (from the point of view of de-motivation) the learning of English in the formal language learning environment. The results of the study suggested that internal and external factors could de-motivate learners if they are perceived negatively. This helps us find out the appropriate ways to increase students' motivation and design some effective strategic plans in English teaching and learning. Additionally, the findings of the study revealed no significant difference among the classes, except for the items related to the effect of teacher's personality and behavior, learners' experience of failure and learners' lack of success. The results also pointed to no significant differences among majors with the exception of the items attending to the effect of teacher's personality and behavior as well as the learners' experience of failure.

Eventually, it must be stated that like many other studies, this study is not without its limitations. For instance, due heed toward other categories of motivation might have helped ameliorate the findings and possibly come up with partially different results. Moreover, the participants were chosen from just one male school in Maragheh and were hence relatively more successful in their learning career. Thus, it seems, a larger sample of students entailing females along with the males, and private school learners in addition to the public school students would have aided the researchers to come up with a more representative sample of Iranian learners, and hence would have rendered the results more generalizable. Finally, the inclusion of more teachers in the study and a better-controlled measurement might have helped shed further light on the phenomenon.

\section{References}

Chambers, G. N. (1998). Pupils' perceptions of the foreign language learning experience. Language Teaching Research, 2(3), 231-259. http://dx.doi.org/10.1191/136216898675051507

Chambers, G. N. (1999). Motivating Language Learners. Clevedon: Multilingual Matters.

Covington, M. V. (1998). The will to learn: A guide for motivating young people. Cambridge: Cambridge University Press.

Dörnyei, Z. (1998a). Motivation in second and foreign language learning. Language Teaching, 31, 117-135. http://dx.doi.org/10.1017/S026144480001315X

Dörnyei, Z. (1998b). Demotivation in foreign language learning. Paper presented at the TESOL '98 Congress, Seattle, WA, March.

Dörnyei, Z. (2001a). Motivational strategies in the language classroom. Cambridge: Cambridge University Press.

Dörnyei, Z. (2001b). Teaching and researching motivation. Harlow: Longman.

Dörnyei, Z., \& Ottó, I. (1998). Motivation in action: A process model of L2 motivation. Working Papers in Applied Linguistics (Thames Valley University, London), 4, 43- 69.

Falout, J., \& Maruyama, M. (2004). A comparative study of proficiency and learner demotivation. The Language Teacher, 28(8), 3-9.

Gardner, R. C. (1985). Social psychology and second language learning: The role of attitudes and motivation. London: Edward Arnold.

Gardner, R. C., \& Lambert, W. E. (1972). Attitudes and motivation in second language learning. Rowley, MA: Newbury House.

Gorham, J., \& Christophel, D. M. (1992). Students' perceptions of teacher behaviors as motivating and demotivating factors in college classes. Communication Quarterly, 40, 239-252. http://dx.doi.org/10.1080/01463379209369839 
Gorham, J., \& Millette, D. (1997). A comparative analysis of teacher and student perceptions of sources of motivation and demotivation in college classes. Communication Education, 46, 245-261. http://dx.doi.org/10.1080/03634529709379099

Hirvonen, M. (2010). Demotivation in learning English among immigrant pupils in the ninth grade of comprehensive school. A Pro Gradu Thesis in English. University of Jyvaskyla.

Muhonen, J. (2004). Second language demotivation: Factors that discourage pupils from learning the English language. Unpublished Thesis. University of Jyväskylä, Department of Languages.

Oxford, R. L. (1998). The unraveling tapestry: Teacher and course characteristics associated with demotivation in foreign language learning. Paper presented at the TESL'98 conference, Seattle, WA.

Sakai, H., \& Kikuchi, K. (2009). An analysis of demotivators in the EFL classroom. System, 37(1), 57-69. http://dx.doi.org/10.1016/j.system.2008.09.005

Trang, T. T. T., \& Baldauf, R. B. (2007). Demotivation: understanding resistance to English language learning - The case of Vietnamese students. The Journal of Asia TEFL, 4(1), 79-105.

Ushioda, E. (1996). Developing a dynamic concept of motivation. In T. J. Hickey (Ed.), Language, education and society in a changing world (pp. 239-245). Clevedon, UK: Multilingual Matters.

Warrington, S. (2005). The Passivity/De-Motivation Inventory. Center for English Language Education, Asia University.

Wlodkowski, R. J. (1986). Enhancing adult motivation to learn. San Francisco, CA: Jossey-Bass.

Table 1. Cronbach's Coefficient Alpha Reliability Estimates

\begin{tabular}{lcr}
\hline Variable & Alpha & Number of items \\
\hline Teachers' teaching method & .7721 & 19 \\
Teacher's personality and behavior & .6300 & 6 \\
Learning material and course content & .6162 & 6 \\
Learning environment & .4239 & 5 \\
Simultaneous learning of many languages & .5123 & 1 \\
Intrinsic motivation & .8609 & 3 \\
Learners' experience of failure & .6920 & 3 \\
Learners' lack of success & .6850 & 4 \\
Attitude & .4247 & 3 \\
\hline
\end{tabular}

Table 2. Rank order of sources of de-motivation

\begin{tabular}{cc}
\hline & Mean Rank \\
\hline Q1A & 5.49 \\
Q1B & 4.44 \\
Q2 & 5.62 \\
Q3 & 6.07 \\
Q4 & 5.91 \\
EX1 & 4.07 \\
EX2 & 5.22 \\
EX3 & 5.17 \\
EX4 & 3.02 \\
\hline
\end{tabular}


Table 3. Chi-Square Test Statistics

\begin{tabular}{|c|c|}
\hline $\mathrm{N}$ & 165 \\
Chi-square & 173.886 \\
$\mathrm{df}$ & 8 \\
Asymp. Sig. & .000 \\
\hline
\end{tabular}

a. Friedman Test

Table 4. Frequency distribution and percentages Relevant to the Effect of teaching method

Q1A

\begin{tabular}{ccccccc}
\hline & & Frequency & Percent & Valid Percent & Cumulative Percent \\
\hline Valid & 1.00 & 5 & 23 & 13.9 & 13.9 & 13.9 \\
& 2.00 & 135 & 81.8 & 81.8 & 95.8 \\
& & 7 & 4.2 & 4.2 & 100.0 \\
& 3.00 & sis & 165 & 100.0 & 100.0 & \\
& & & & \\
\hline
\end{tabular}

Table 5. Frequency distribution and percentages Relevant to the Effect of teacher personality and behavior Q1B

\begin{tabular}{ccccccc}
\hline & & & Frequency & Percent & Valid Percent & Cumulative Percent \\
\hline Valid & 1.00 & S & 65 & 39.4 & 39.4 & 39.4 \\
& 2.00 & & 88 & 53.3 & 53.3 & 92.7 \\
& & 12 & 7.3 & 7.3 & 100.0 \\
& 3.00 & sis & 165 & 100.0 & 100.0 & \\
& & & & & \\
\hline
\end{tabular}

Table 6. Frequency distribution and percentages Relevant to the Effect of learning material and course content Q2

\begin{tabular}{ccccccc}
\hline & & Frequency & Percent & Valid Percent & Cumulative Percent \\
\hline Valid & 1.00 & S & 36 & 21.8 & 21.8 & 21.8 \\
& 2.00 & 118 & 71.5 & 71.5 & 93.3 \\
& & 11 & 6.7 & 6.7 & 100.0 \\
& 3.00 & sis & 165 & 100.0 & 100.0 & \\
& & & & & \\
\hline
\end{tabular}

Table 7. Frequency distribution and percentages Relevant to the Effect of learning environment Q3

\begin{tabular}{ccccccc}
\hline & & Frequency & Percent & Valid Percent & Cumulative Percent \\
\hline Valid & 1.00 & 5 & 25 & 15.2 & 15.2 & 15.2 \\
& 2.00 & 111 & 67.3 & 67.3 & 82.4 \\
& 5 منوسط & 29 & 17.6 & 17.6 & 100.0 \\
& 3.00 & 165 & 100.0 & 100.0 & \\
& & & & \\
\hline
\end{tabular}


Table 8. Frequency distribution and percentages Relevant to the Effect of simultaneous learning of other languages

Q4

\begin{tabular}{clccccc}
\hline & & & Frequency & Percent & Valid Percent & Cumulative Percent \\
\hline Valid & 1.00 & 5 & 57 & 34.5 & 34.5 & 34.5 \\
& 2.00 & & 35 & 21.2 & 21.2 & 55.8 \\
& & 73 & 44.2 & 44.2 & 100.0 \\
& 3.00 & متوسط & 165 & 100.0 & 100.0 & \\
& Total & & & & & \\
\hline
\end{tabular}

Table 9. Frequency distribution and percentages Relevant to the Effect of learner characteristics

EX1

\begin{tabular}{ccccccc}
\hline & & & Frequency & Percent & Valid Percent & Cumulative Percent \\
\hline Valid & 1.00 & S & 82 & 49.7 & 49.7 & 49.7 \\
& 2.00 & & 79 & 47.9 & 47.9 & 97.6 \\
& & 4 & 2.4 & 2.4 & 100.0 \\
& 3.00 & منوسي & 165 & 100.0 & 100.0 & \\
& Total & & & & \\
\hline
\end{tabular}

Table 10. Frequency distribution and percentages Relevant to the Effect of learners' experience of failure

EX2

\begin{tabular}{clccccc}
\hline & & & Frequency & Percent & Valid Percent & Cumulative Percent \\
\hline Valid & 1.00 & 5 & 67 & 40.6 & 40.6 & 40.6 \\
& 2.00 & & 58 & 35.2 & 35.2 & 75.8 \\
& & 40 & 24.2 & 24.2 & 100.0 \\
& 3.00 & من & 165 & 100.0 & 100.0 & \\
& Total & & & & & \\
\hline
\end{tabular}

Table 11. Frequency distribution and percentages Relevant to the Effect of learners' lack of success EX3

\begin{tabular}{|c|c|c|c|c|c|c|}
\hline & & & Frequency & Percent & Valid Percent & Cumulative Percent \\
\hline \multirow[t]{5}{*}{ Valid } & 1.00 & كم & 54 & 32.7 & 32.7 & 32.7 \\
\hline & 2.00 & & 91 & 55.2 & 55.2 & 87.9 \\
\hline & متوسط & & 20 & 12.1 & 12.1 & 100.0 \\
\hline & 3.00 & زياد & 165 & 100.0 & 100.0 & \\
\hline & Total & & & & & \\
\hline
\end{tabular}

Table 12. Frequency distribution and percentages Relevant to the Effect of learners' Attitude

EX4

\begin{tabular}{|c|c|c|c|c|c|c|}
\hline & & & Frequency & Percent & Valid Percent & Cumulative Percent \\
\hline \multirow{4}{*}{ Valid } & 1.00 & 5 & 108 & 65.5 & 65.5 & 65.5 \\
\hline & 2.00 & & 56 & 33.9 & 33.9 & 99.4 \\
\hline & متوسط & & 1 & .6 & 6 & 100.0 \\
\hline & $\begin{array}{l}3.00 \\
\text { Total }\end{array}$ & 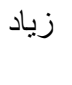 & 165 & 100.0 & 100.0 & \\
\hline
\end{tabular}


Table 13. Chi-Square Test Frequencies of Q1A

\begin{tabular}{cccccc}
\hline & & Observed N & Expected N & Residual \\
\hline Valid & 1.00 & S & 23 & 55.0 & -32.0 \\
& 2.00 & 135 & 55.0 & 80.0 \\
& & 7 & 55.0 & -48.0 \\
& 3.00 & منوسط & 165 & & \\
& Total & & & \\
\hline
\end{tabular}

Table 14. Chi-Square Test Results of Q1A

\begin{tabular}{|c|c|}
\hline & Q1A \\
\hline Chi-square & 176.873 \\
df & 2 \\
Asymp. Sig. & .000 \\
\hline
\end{tabular}

Table 15. Chi-Square Test Frequencies of Q1B

\begin{tabular}{cccccc}
\hline & & & Observed N & Expected N & Residual \\
\hline Valid & 1.00 & 5 & 65 & 55.0 & 10.0 \\
& 2.00 & & 88 & 55.0 & 33.0 \\
& Sib & 12 & 55.0 & -43.0 \\
& 3.00 & مياد & 165 & & \\
& Total & & & \\
\hline
\end{tabular}

Table 16. Chi-Square Test Results of Q1B

\begin{tabular}{|c|c|}
\hline & Q1B \\
\hline Chi-square & 55.236 \\
df & 2 \\
Asymp. Sig. & .000 \\
\hline
\end{tabular}

Table 17. Chi-Square Test Frequencies of Q2

\begin{tabular}{cccccc}
\hline & & & Observed N & Expected N & Residual \\
\hline Valid & 1.00 & \multirow{6}{*}{ S } & 36 & 55.0 & -19.0 \\
& 2.00 & 118 & 55.0 & 63.0 \\
& & 11 & 55.0 & -44.0 \\
& 3.00 & منوسط & 165 & & \\
& Total & & & \\
\hline
\end{tabular}

Table 18. Chi-Square Test Results of Q2

\begin{tabular}{|c|c|}
\hline & Q2 \\
\hline Chi-square & 113.927 \\
df & 2 \\
Asymp. Sig. & .000 \\
\hline
\end{tabular}


Table 19. Chi-Square Test Frequencies of Q3

\begin{tabular}{cccccc}
\hline & & Observed N & Expected N & Residual \\
\hline Valid & 1.00 & 5 & 25 & 55.0 & -30.0 \\
& 2.00 & 111 & 55.0 & 56.0 \\
& & 29 & 55.0 & -26.0 \\
& 3.00 & sis & 165 & & \\
& Total & & & \\
\hline
\end{tabular}

Table 20. Chi-Square Test Results of Q3

\begin{tabular}{|c|c|}
\hline & Q3 \\
\hline Chi-square & 85.673 \\
df & 2 \\
Asymp. Sig. & .000 \\
\hline
\end{tabular}

Table 21. Chi-Square Test Frequencies of Q4

\begin{tabular}{cccccc}
\hline & & Observed N & Expected N & Residual \\
\hline Valid & 1.00 & 5 & 57 & 55.0 & 2.0 \\
& 2.00 & 35 & 55.0 & -20.0 \\
& 5 منوسط & 73 & 55.0 & 18.0 \\
& 3.00 & 165 & & \\
& Total & & & \\
\hline
\end{tabular}

Table 22. Chi-Square Test Results of Q4

\begin{tabular}{|c|c|}
\hline & Q4 \\
\hline Chi-square & 13.236 \\
df & 2 \\
Asymp. Sig. & .001 \\
\hline
\end{tabular}

Table 23. Chi-Square Test Frequencies of EX1

\begin{tabular}{cccccc}
\hline & & & Observed N & Expected N & Residual \\
\hline Valid & 1.00 & 5 & 82 & 55.0 & 27.0 \\
& 2.00 & 79 & 55.0 & 24.0 \\
& 5 منوسط & 4 & 55.0 & -51.0 \\
& 3.00 & 165 & & \\
& Total & & & & \\
\hline
\end{tabular}

Table 24. Chi-Square Test Results of EX1

\begin{tabular}{|c|c|}
\hline & EX1 \\
\hline Chi-square & 71.018 \\
df & 2 \\
Asymp. Sig. & .000 \\
\hline
\end{tabular}


Table 25. Chi-Square Test Frequencies of EX2

\begin{tabular}{|c|c|c|c|c|c|}
\hline & & & Observed $\mathrm{N}$ & Expected N & Residual \\
\hline \multirow[t]{5}{*}{ Valid } & 1.00 & كم & 67 & 55.0 & 12.0 \\
\hline & 2.00 & & 58 & 55.0 & 3.0 \\
\hline & منوسط & & 40 & 55.0 & -15.0 \\
\hline & 3.00 & زياد & 165 & & \\
\hline & Total & & & & \\
\hline
\end{tabular}

Table 26. Chi-Square Test Results of EX2

\begin{tabular}{|c|c|}
\hline & EX2 \\
\hline Chi-square & 6.873 \\
df & 2 \\
Asymp. Sig. & .032 \\
\hline
\end{tabular}

Table 27. Chi-Square Test Frequencies of EX3

\begin{tabular}{cccccc}
\hline & & Observed N & Expected N & Residual \\
\hline Valid & 1.00 & 5 & 54 & 55.0 & -1.0 \\
& 2.00 & 91 & 55.0 & 36.0 \\
& & 20 & 55.0 & -35.0 \\
& 3.00 & منوسط & 165 & & \\
& Total & & & \\
\hline
\end{tabular}

Table 28. Chi-Square Test Results of EX3

\begin{tabular}{|c|c|}
\hline & EX3 \\
\hline Chi-square & 45.855 \\
df & 2 \\
Asymp. Sig. & .000 \\
\hline
\end{tabular}

Table 29. Chi-Square Test Frequencies of EX4

\begin{tabular}{cccccc}
\hline & & & Observed N & Expected N & Residual \\
\hline Valid & 1.00 & S & 108 & 55.0 & 53.0 \\
& 2.00 & 56 & 55.0 & 1.0 \\
& & 1 & 55.0 & -54.0 \\
& 3.00 & منوسط & 165 & & \\
& Total & & & \\
\hline
\end{tabular}

Table 30. Chi-Square Test Results of EX4

\begin{tabular}{|c|c|}
\hline & EX4 \\
\hline Chi-square & 104.109 \\
df & 2 \\
Asymp. Sig. & .000 \\
\hline
\end{tabular}


Table 31. Descriptive Statistics of Q1A in Six Classes

\begin{tabular}{|c|c|c|c|c|c|c|c|c|}
\hline & & & $\mathrm{N}$ & Mean & Std. Deviation & Std. Error & Minimum & Maximum \\
\hline \multirow[t]{7}{*}{ Q1A } & $\begin{array}{l}1.00 \\
1\end{array}$ & سوم رياضى & 23 & 1.9565 & .47465 & .09897 & 1.00 & 3.00 \\
\hline & 2.00 & سوم تجربى & 31 & 2.0000 & .25820 & .04637 & 1.00 & 3.00 \\
\hline & 3.00 & اول 1 & 30 & 1.8667 & .34575 & .06312 & 1.00 & 2.00 \\
\hline & $\begin{array}{l}4.00 \\
2\end{array}$ & سوم رياضى & 25 & 1.8800 & .33166 & .06633 & 1.00 & 2.00 \\
\hline & 5.00 & دوم تجربى 3 & 28 & 1.9643 & .42879 & .08103 & 1.00 & 3.00 \\
\hline & 6.00 & اول 2 & 28 & 1.7500 & .58531 & .11061 & 1.00 & 3.00 \\
\hline & Total & & 165 & 1.9030 & .41649 & .03242 & 1.00 & 3.00 \\
\hline
\end{tabular}

Table 32. A One Way Analysis of Variance of Q1A among Classes

\begin{tabular}{llccccc}
\hline & & Sum of Squares & df & Mean Square & F & Sig. \\
\hline Q1A & Between Groups & 1.171 & 5 & .234 & 1.365 & .240 \\
& Within Groups & 27.277 & 159 & .172 & & \\
& Total & 28.448 & 164 & & & \\
\hline
\end{tabular}

Table 33. Descriptive Statistics of Q1B in Six Classes

\begin{tabular}{|c|c|c|c|c|c|c|c|c|}
\hline & & & $\mathrm{N}$ & Mean & Std. Deviation & Std. Error & Minimum & Maximum \\
\hline \multirow[t]{8}{*}{ Q1B } & 1.00 & سوم رياضى & 23 & 1.8261 & .57621 & .12015 & 1.00 & 3.00 \\
\hline & 1 & & & & & & & \\
\hline & 2.00 & سوم تجربى & 31 & 2.1935 & .40161 & .07213 & 2.00 & 3.00 \\
\hline & 3.00 & اول 1 & 30 & 1.3333 & .60648 & .11073 & 1.00 & 3.00 \\
\hline & $\begin{array}{l}4.00 \\
2\end{array}$ & سوم رياضى & 25 & 1.7600 & .43589 & .08718 & 1.00 & 2.00 \\
\hline & 5.00 & دوم تجربى 3 & 28 & 1.7143 & .59982 & .11336 & 1.00 & 3.00 \\
\hline & 6.00 & اول 2 & 28 & 1.2500 & .44096 & .08333 & 1.00 & 2.00 \\
\hline & Total & & 165 & 1.6788 & .60474 & .04708 & 1.00 & 3.00 \\
\hline
\end{tabular}

Table 34. A One Way Analysis of Variance of Q1B among Classes

\begin{tabular}{llccccc}
\hline & & Sum of Squares & df & Mean Square & F & Sig. \\
\hline Q1B & Between Groups & 17.642 & 5 & 3.528 & 13.252 & .000 \\
& Within Groups & 42.334 & 159 & .266 & & \\
Total & 59.976 & 164 & & & \\
\hline
\end{tabular}

Table 35. Descriptive Statistics of Q2 in Six Classes

\begin{tabular}{|c|c|c|c|c|c|c|c|c|}
\hline & & & $\mathrm{N}$ & Mean & Std. Deviation & Std. Error & Minimum & Maximum \\
\hline \multirow[t]{9}{*}{ Q2 } & 1.00 & سوم رياضى & 23 & 1.7826 & .42174 & .08794 & 1.00 & 2.00 \\
\hline & 1 & & & & & & & \\
\hline & 2.00 & سوم تجربى & 31 & 1.9677 & .54674 & .09820 & 1.00 & 3.00 \\
\hline & 3.00 & اول 1 & 30 & 1.8000 & .55086 & .10057 & 1.00 & 3.00 \\
\hline & 4.00 & سوم رياضى & 25 & 1.8000 & .50000 & .10000 & 1.00 & 3.00 \\
\hline & 2 & & & & & & & \\
\hline & 5.00 & دوم تجربى 3 & 28 & 1.7857 & .56811 & .10736 & 1.00 & 3.00 \\
\hline & 6.00 & اول 2 & 28 & 1.9286 & .46576 & .08802 & 1.00 & 3.00 \\
\hline & Total & & 165 & 1.8485 & .51331 & .03996 & 1.00 & 3.00 \\
\hline
\end{tabular}


Table 36. A One Way Analysis of Variance of Q2 among Classes

\begin{tabular}{llccccc}
\hline & Sum of Squares & df & Mean Square & F & Sig. \\
\hline \multirow{2}{*}{ Q2 } & Between Groups & .960 & 5 & .192 & .722 & .608 \\
& Within Groups & 42.252 & 159 & .266 & & \\
Total & 43.212 & 164 & & & \\
\hline
\end{tabular}

Table 37. Descriptive Statistics of Q3 in Six Classes

\begin{tabular}{|c|c|c|c|c|c|c|c|c|}
\hline & & & $\mathrm{N}$ & Mean & Std. Deviation & Std. Error & Minimum & Maximum \\
\hline \multirow[t]{9}{*}{ Q3 } & 1.00 & سوم رياضى & 23 & 1.8696 & .69442 & .14480 & 1.00 & 3.00 \\
\hline & 1 & & & & & & & \\
\hline & 2.00 & سوم تجربى & 31 & 2.0645 & .51222 & .09200 & 1.00 & 3.00 \\
\hline & 3.00 & اول 1 & 30 & 2.1000 & .54772 & .10000 & 1.00 & 3.00 \\
\hline & 4.00 & سوم رياضى & 25 & 2.0000 & .28868 & .05774 & 1.00 & 3.00 \\
\hline & 2 & & & & & & & \\
\hline & 5.00 & دوم تجربى 3 & 28 & 2.1429 & .59094 & .11168 & 1.00 & 3.00 \\
\hline & 6.00 & اول 2 & 28 & 1.9286 & .71640 & .13539 & 1.00 & 3.00 \\
\hline & Total & & 165 & 2.0242 & .57330 & .04463 & 1.00 & 3.00 \\
\hline
\end{tabular}

Table 38. A One Way Analysis of Variance of Q3 among Classes

\begin{tabular}{llccccc}
\hline & & Sum of Squares & df & Mean Square & F & Sig. \\
\hline \multirow{2}{*}{ Q3 } & Between Groups & 1.438 & 5 & .288 & .871 & .502 \\
& Within Groups & 52.465 & 159 & .330 & & \\
Total & 53.903 & 164 & & & \\
\hline
\end{tabular}

Table 39. Descriptive Statistics of Q4 in Six Classes

\begin{tabular}{|c|c|c|c|c|c|c|c|c|}
\hline & & & $\mathrm{N}$ & Mean & Std. Deviation & Std. Error & Minimum & Maximum \\
\hline \multirow[t]{9}{*}{ Q4 } & 1.00 & سوم رياضى & 23 & 2.3913 & .89133 & .18585 & 1.00 & 3.00 \\
\hline & 1 & & & & & & & \\
\hline & 2.00 & سوم تجربى & 31 & 2.1290 & .92166 & .16554 & 1.00 & 3.00 \\
\hline & 3.00 & اول 1 & 30 & 2.2333 & .81720 & .14920 & 1.00 & 3.00 \\
\hline & 4.00 & سوم رياضى & 25 & 1.7200 & .84261 & .16852 & 1.00 & 3.00 \\
\hline & 2 & & & & & & & \\
\hline & 5.00 & دوم تجربى 3 & 28 & 2.0357 & .92224 & .17429 & 1.00 & 3.00 \\
\hline & 6.00 & اول 2 & 28 & 2.0714 & .85758 & .16207 & 1.00 & 3.00 \\
\hline & Total & & 165 & 2.0970 & .88500 & .06890 & 1.00 & 3.00 \\
\hline
\end{tabular}

Table 40. A One Way Analysis of Variance of Q4 among Classes

\begin{tabular}{clccccc}
\hline & & Sum of Squares & df & Mean Square & F & Sig. \\
\hline \multirow{2}{*}{ Q4 } & Between Groups & 6.258 & 5 & 1.252 & 1.629 & .155 \\
& Within Groups & 122.190 & 159 & .768 & & \\
Total & 128.448 & 164 & & & \\
\hline
\end{tabular}


Table 41. Descriptive Statistics of EX1 in Six Classes

\begin{tabular}{|c|c|c|c|c|c|c|c|c|}
\hline & & & $\mathrm{N}$ & Mean & Std. Deviation & Std. Error & Minimum & Maximum \\
\hline \multirow[t]{9}{*}{ EX1 } & 1.00 & سوم رياضى & 23 & 1.4783 & .59311 & .12367 & 1.00 & 3.00 \\
\hline & 1 & & & & & & & \\
\hline & 2.00 & سوم تجربى & 31 & 1.6774 & .54081 & .09713 & 1.00 & 3.00 \\
\hline & 3.00 & اول 1 & 30 & 1.5000 & .57235 & .10450 & 1.00 & 3.00 \\
\hline & 4.00 & سوم رياضى & 25 & 1.6000 & .57735 & .11547 & 1.00 & 3.00 \\
\hline & 2 & & & & & & & \\
\hline & 5.00 & دوم تجربى 3 & 28 & 1.3571 & .48795 & .09221 & 1.00 & 2.00 \\
\hline & 6.00 & اول 2 & 28 & 1.5357 & .50787 & .09598 & 1.00 & 2.00 \\
\hline & Total & & 165 & 1.5273 & .54732 & .04261 & 1.00 & 3.00 \\
\hline
\end{tabular}

Table 42. A One Way Analysis of Variance of EX1 among Classes

\begin{tabular}{llccccc}
\hline & & Sum of Squares & df & Mean Square & F & Sig. \\
\hline EX1 & Between Groups & 1.721 & 5 & .344 & 1.155 & .334 \\
& Within Groups & 47.406 & 159 & .298 & & \\
& Total & 49.127 & 164 & & & \\
\hline
\end{tabular}

Table 43. Descriptive Statistics of EX2 in Six Classes

\begin{tabular}{|c|c|c|c|c|c|c|c|c|}
\hline & & & $\mathrm{N}$ & Mean & Std. Deviation & Std. Error & Minimum & Maximum \\
\hline \multirow[t]{8}{*}{ EX2 } & 1.00 & سوم رياضى & 23 & 1.9565 & .70751 & .14715 & 1.00 & 3.00 \\
\hline & 1 & & & & & & & \\
\hline & 2.00 & سوم تجربى & 31 & 2.3871 & .71542 & .12849 & 1.00 & 3.00 \\
\hline & 3.00 & اول 1 & 30 & 1.6667 & .71116 & .12984 & 1.00 & 3.00 \\
\hline & $\begin{array}{l}4.00 \\
2\end{array}$ & سوم رياضى & 25 & 1.6800 & .80208 & .16042 & 1.00 & 3.00 \\
\hline & 5.00 & دوم تجربى 3 & 28 & 1.8214 & .77237 & .14596 & 1.00 & 3.00 \\
\hline & 6.00 & اول 2 & 28 & 1.4643 & .74447 & .14069 & 1.00 & 3.00 \\
\hline & Total & & 165 & 1.8364 & .79088 & .06157 & 1.00 & 3.00 \\
\hline
\end{tabular}

Table 44. A One Way Analysis of Variance of EX2 among Classes

\begin{tabular}{llccccc}
\hline & & Sum of Squares & df & Mean Square & F & Sig. \\
\hline EX2 & Between Groups & 15.092 & 5 & 3.018 & 5.486 & .000 \\
& Within Groups & 87.489 & 159 & .550 & & \\
Total & 102.582 & 164 & & & \\
\hline
\end{tabular}

Table 45. Descriptive Statistics of EX3 in Six Classes

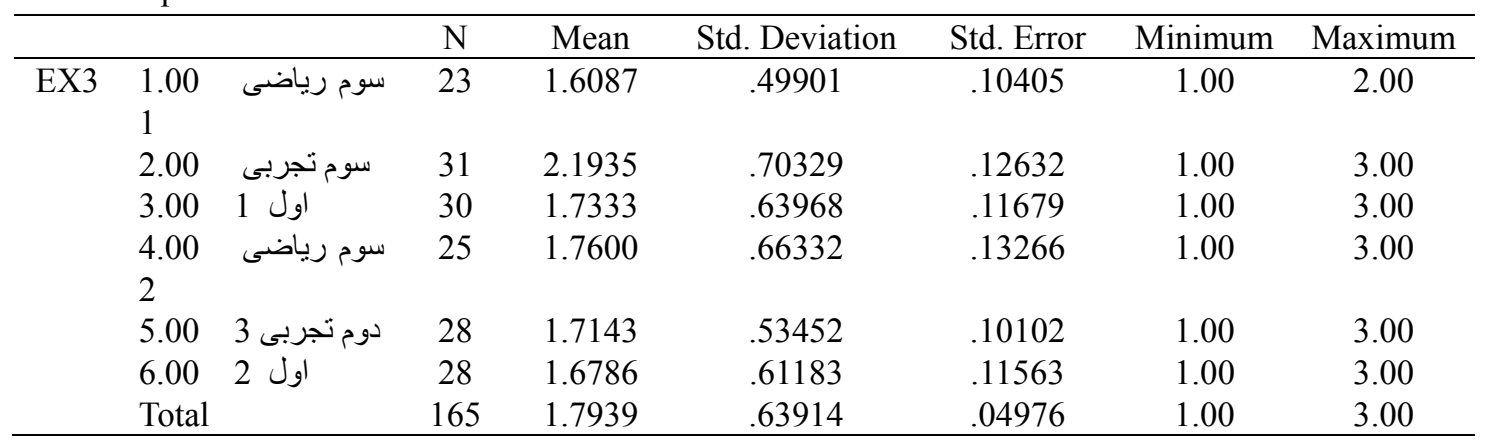


Table 46. A One Way Analysis of Variance of EX3 among Classes

\begin{tabular}{llccccc}
\hline & & Sum of Squares & df & Mean Square & F & Sig. \\
\hline EX3 & Between Groups & 6.429 & 5 & 1.286 & 3.376 & .006 \\
& Within Groups & 60.565 & 159 & .381 & & \\
Total & 66.994 & 164 & & & \\
\hline
\end{tabular}

Table 47. Descriptive Statistics of EX4 in Six Classes

\begin{tabular}{|c|c|c|c|c|c|c|c|c|}
\hline & & & $\mathrm{N}$ & Mean & Std. Deviation & Std. Error & Minimum & Maximum \\
\hline \multirow[t]{7}{*}{ EX4 } & $\begin{array}{l}1.00 \\
1\end{array}$ & سوم رياضى & 23 & 1.3913 & 49901 & .10405 & 1.00 & 2.00 \\
\hline & 2.00 & سوم تجربى & 31 & 1.4194 & .50161 & .09009 & 1.00 & 2.00 \\
\hline & 3.00 & اول 1 & 30 & 1.2333 & .43018 & .07854 & 1.00 & 2.00 \\
\hline & $\begin{array}{l}4.00 \\
2\end{array}$ & سوم رياضى & 25 & 1.3200 & .47610 & .09522 & 1.00 & 2.00 \\
\hline & 5.00 & دوم تجربى 3 & 28 & 1.4286 & .50395 & .09524 & 1.00 & 2.00 \\
\hline & 6.00 & اول 2 & 28 & 1.3214 & .54796 & .10356 & 1.00 & 3.00 \\
\hline & Total & & 165 & 1.3515 & .49146 & .03826 & 1.00 & 3.00 \\
\hline
\end{tabular}

Table 48. A One Way Analysis of Variance of EX4 among Classes

\begin{tabular}{llccccc}
\hline & & Sum of Squares & df & Mean Square & F & Sig. \\
\hline EX4 & Between Groups & .815 & 5 & .163 & .668 & .649 \\
& Within Groups & 38.798 & 159 & .244 & & \\
Total & 39.612 & 164 & & & \\
\hline
\end{tabular}

Table 49. Descriptive Statistics of Q1A among Majors

\begin{tabular}{cccccccc}
\hline & & $\mathrm{N}$ & Mean & Std. Deviation & Std. Error & Minimum & Maximum \\
\hline Q1A اول & 58 & 1.8103 & .47598 & .06250 & 1.00 & 3.00 \\
& 48 & 1.9167 & .40388 & .05830 & 1.00 & 3.00 \\
& رياضى & 59 & 1.9831 & .34698 & .04517 & 1.00 & 3.00 \\
& Total & 165 & 1.9030 & .41649 & .03242 & 1.00 & 3.00 \\
\hline
\end{tabular}

Table 50. One Way Analysis of Variance of Q1A among Majors

\begin{tabular}{llccccc}
\hline & & Sum of Squares & df & Mean Square & F & Sig. \\
\hline Q1A & Between Groups & .885 & 2 & .442 & 2.601 & .077 \\
& Within Groups & 27.564 & 162 & .170 & & \\
Total & 28.448 & 164 & & & \\
\hline
\end{tabular}

Table 51. Descriptive Statistics of Q1B among Majors

\begin{tabular}{cccccccc}
\hline & & $\mathrm{N}$ & Mean & Std. Deviation & Std. Error & Minimum & Maximum \\
\hline Q1B & 58 & 1.2931 & .53010 & .06961 & 1.00 & 3.00 \\
& اولى & 48 & 1.7917 & .50353 & .07268 & 1.00 & 3.00 \\
& 59 & 1.9661 & .55604 & .07239 & 1.00 & 3.00 \\
& Total & 165 & 1.6788 & .60474 & .04708 & 1.00 & 3.00 \\
\hline
\end{tabular}


Table 52. One Way Analysis of Variance of Q1B among Majors

\begin{tabular}{llccccc}
\hline & & Sum of Squares & df & Mean Square & F & Sig. \\
\hline Q1B & Between Groups & 14.110 & 2 & 7.055 & 24.918 & .000 \\
& Within Groups & 45.866 & 162 & .283 & & \\
& Total & 59.976 & 164 & & & \\
\hline
\end{tabular}

Table 53. Descriptive Statistics of Q2 among Majors

\begin{tabular}{cccccccc}
\hline & & $\mathrm{N}$ & Mean & Std. Deviation & Std. Error & Minimum & Maximum \\
\hline Q2 & 58 & 1.8621 & .51122 & .06713 & 1.00 & 3.00 \\
& 48 & 1.7917 & .45934 & .06630 & 1.00 & 3.00 \\
& رولجى & 59 & 1.8814 & .55970 & .07287 & 1.00 & 3.00 \\
& Total & 165 & 1.8485 & .51331 & .03996 & 1.00 & 3.00 \\
\hline
\end{tabular}

Table 54. One Way Analysis of Variance of Q2 among Majors

\begin{tabular}{llccccc}
\hline & & Sum of Squares & df & Mean Square & F & Sig. \\
\hline Q2 & Between Groups & .229 & 2 & .115 & .432 & .650 \\
Within Groups & 42.983 & 162 & .265 & & \\
Total & 43.212 & 164 & & & \\
\hline
\end{tabular}

Table 55. Descriptive Statistics of Q3 among Majors

\begin{tabular}{cccccccc}
\hline & & $\mathrm{N}$ & Mean & Std. Deviation & Std. Error & Minimum & Maximum \\
\hline Q3 & 58 & 2.0172 & .63499 & .08338 & 1.00 & 3.00 \\
& 48 & 1.9375 & .52212 & .07536 & 1.00 & 3.00 \\
& (وياضى & 49 & 2.1017 & .54756 & .07129 & 1.00 & 3.00 \\
& Total & 165 & 2.0242 & .57330 & .04463 & 1.00 & 3.00 \\
\hline
\end{tabular}

Table 56. One Way Analysis of Variance of Q3 among Majors

\begin{tabular}{llccccc}
\hline & & Sum of Squares & df & Mean Square & F & Sig. \\
\hline Q3 & Between Groups & .718 & 2 & .359 & 1.093 & .338 \\
& Within Groups & 53.185 & 162 & .328 & & \\
Total & 53.903 & 164 & & & \\
\hline
\end{tabular}

Table 57. Descriptive Statistics of Q4 among Majors

\begin{tabular}{cccccccc}
\hline & & $\mathrm{N}$ & Mean & Std. Deviation & Std. Error & Minimum & Maximum \\
\hline Q4 & 58 & 2.1552 & .83355 & .10945 & 1.00 & 3.00 \\
& 48 & 2.0417 & .92157 & .13302 & 1.00 & 3.00 \\
& رياضى & 48 & 2.0847 & .91516 & .11914 & 1.00 & 3.00 \\
& Total & 165 & 2.0970 & .88500 & .06890 & 1.00 & 3.00 \\
\hline
\end{tabular}


Table 58. One Way Analysis of Variance of Q4 among Majors

\begin{tabular}{llccccc}
\hline & & Sum of Squares & df & Mean Square & F & Sig. \\
\hline Q4 & Between Groups & .352 & 2 & .176 & .223 & .801 \\
& Within Groups & 128.096 & 162 & .791 & & \\
Total & 128.448 & 164 & & & \\
\hline
\end{tabular}

Table 59. Descriptive Statistics of EX1 among Majors

\begin{tabular}{cccccccc}
\hline & & $\mathrm{N}$ & Mean & Std. Deviation & Std. Error & Minimum & Maximum \\
\hline EX1 اول & 58 & 1.5172 & .53775 & .07061 & 1.00 & 3.00 \\
& 48 & 1.5417 & .58194 & .08400 & 1.00 & 3.00 \\
& رياضى & 49 & 1.5254 & .53678 & .06988 & 1.00 & 3.00 \\
& Total & 165 & 1.5273 & .54732 & .04261 & 1.00 & 3.00 \\
\hline
\end{tabular}

Table 60. One Way Analysis of Variance of EX1 among Majors

\begin{tabular}{llccccc}
\hline & & Sum of Squares & df & Mean Square & F & Sig. \\
\hline EX1 & Between Groups & .016 & 2 & .008 & .026 & .974 \\
& Within Groups & 49.111 & 162 & .303 & & \\
Total & 49.127 & 164 & & & \\
\hline
\end{tabular}

Table 61. Descriptive Statistics of EX2 among Majors

\begin{tabular}{cccccccc}
\hline & & $\mathrm{N}$ & Mean & Std. Deviation & Std. Error & Minimum & Maximum \\
\hline EX2 اول & 58 & 1.5690 & .72818 & .09561 & 1.00 & 3.00 \\
& 48 & 1.8125 & .76231 & .11003 & 1.00 & 3.00 \\
& رياضى & 59 & 2.1186 & .78969 & .10281 & 1.00 & 3.00 \\
& Total & 165 & 1.8364 & .79088 & .06157 & 1.00 & 3.00 \\
\hline
\end{tabular}

Table 62. One Way Analysis of Variance of EX2 among Majors

\begin{tabular}{llccccc}
\hline & & Sum of Squares & df & Mean Square & F & Sig. \\
\hline EX2 & Between Groups & 8.876 & 2 & 4.438 & 7.672 & .001 \\
& Within Groups & 93.706 & 162 & .578 & & \\
Total & 102.582 & 164 & & & \\
\hline
\end{tabular}

Table 63. Descriptive Statistics of EX3 among Majors

\begin{tabular}{cccccccc}
\hline & & $\mathrm{N}$ & Mean & Std. Deviation & Std. Error & Minimum & Maximum \\
\hline EX3 اول & 58 & 1.7069 & .62150 & .08161 & 1.00 & 3.00 \\
& 48 & 1.6875 & .58913 & .08503 & 1.00 & 3.00 \\
& رياضى & 59 & 1.9661 & .66866 & .08705 & 1.00 & 3.00 \\
& Total & 165 & 1.7939 & .63914 & .04976 & 1.00 & 3.00 \\
\hline
\end{tabular}


Table 64. One Way Analysis of Variance of EX3 among Majors

\begin{tabular}{llccccc}
\hline & & Sum of Squares & df & Mean Square & F & Sig. \\
\hline \multirow{2}{*}{ EX3 } & Between Groups & 2.732 & 2 & 1.366 & 3.444 & .034 \\
& Within Groups & 64.262 & 162 & .397 & & \\
Total & 66.994 & 164 & & & \\
\hline
\end{tabular}

Table 65. Descriptive Statistics of EX4 among Majors

\begin{tabular}{|c|c|c|c|c|c|c|c|}
\hline & & $\mathrm{N}$ & Mean & Std. Deviation & Std. Error & Minimum & Maximum \\
\hline \multirow[t]{4}{*}{ EX4 } & اول & 58 & 1.2759 & .48822 & .06411 & 1.00 & 3.00 \\
\hline & رياضى & 48 & 1.3542 & .48332 & .06976 & 1.00 & 2.00 \\
\hline & تجربى & 59 & 1.4237 & .49839 & .06488 & 1.00 & 2.00 \\
\hline & Total & 165 & 1.3515 & .49146 & .03826 & 1.00 & 3.00 \\
\hline
\end{tabular}

Table 66. One Way Analysis of Variance of EX4 among Majors

\begin{tabular}{llccccc}
\hline & & Sum of Squares & df & Mean Square & F & Sig. \\
\hline \multirow{2}{*}{ EX4 } & Between Groups & .640 & 2 & .320 & 1.330 & .267 \\
& Within Groups & 38.972 & 162 & .241 & & \\
& Total & 39.612 & 164 & & & \\
\hline
\end{tabular}

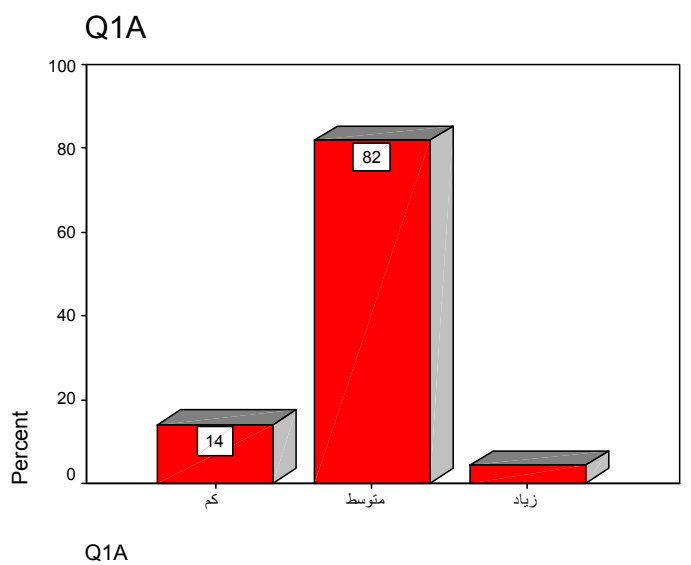

Figure 1. Frequency distribution and percentages Relevant to the Effect of teaching method 


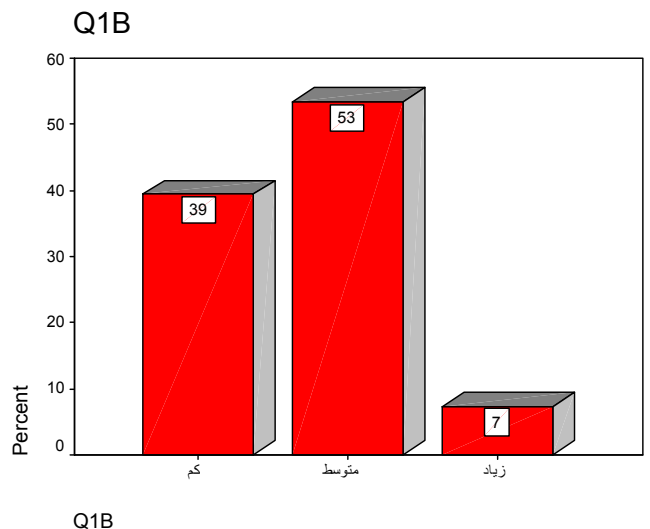

Figure 2. Frequency distribution and percentages Relevant to the Effect of teacher personality and behavior

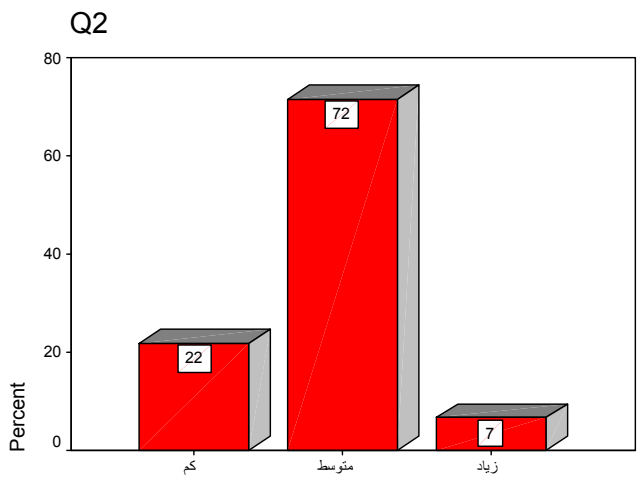

Q2

Figure 3. Frequency distribution and percentages Relevant to the Effect of learning material and course content

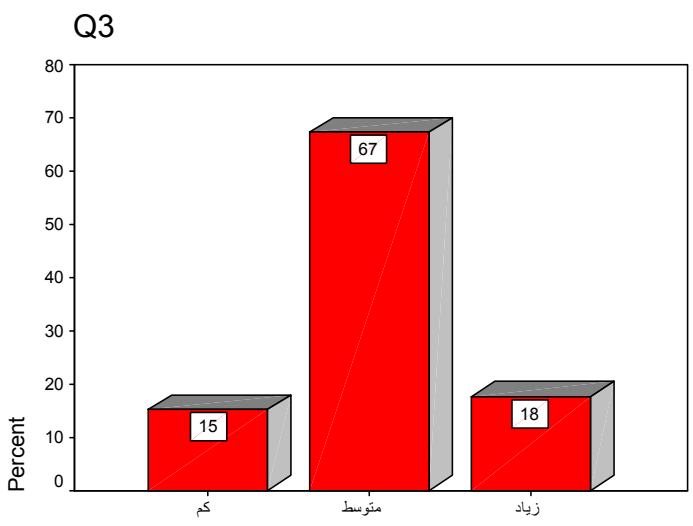

Q3

Figure 4. Frequency distribution and percentages Relevant to the Effect of learning environment 


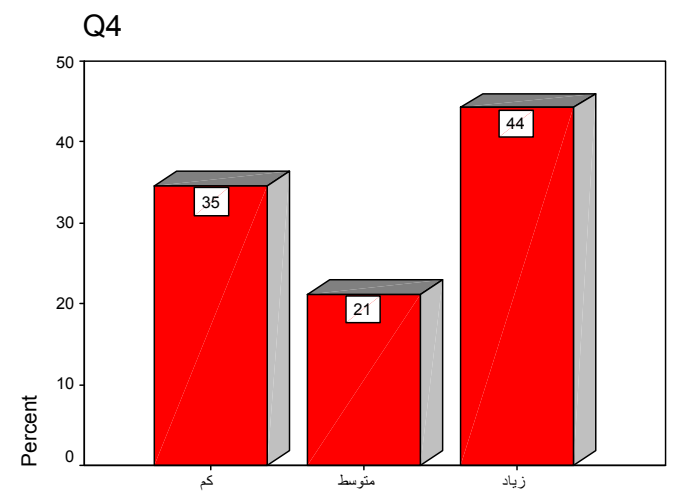

Q4

Figure 5. Frequency distribution and percentages Relevant to the Effect of simultaneous learning of other languages

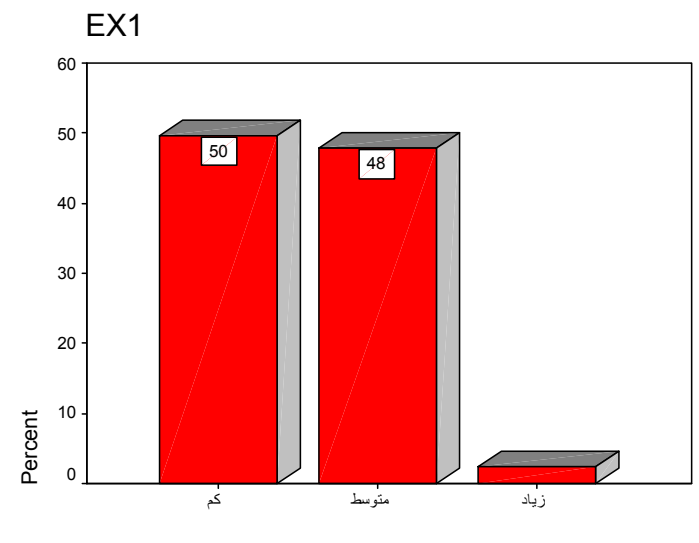

EX1

Figure 6. Frequency distribution and percentages Relevant to the Effect of learner characteristics

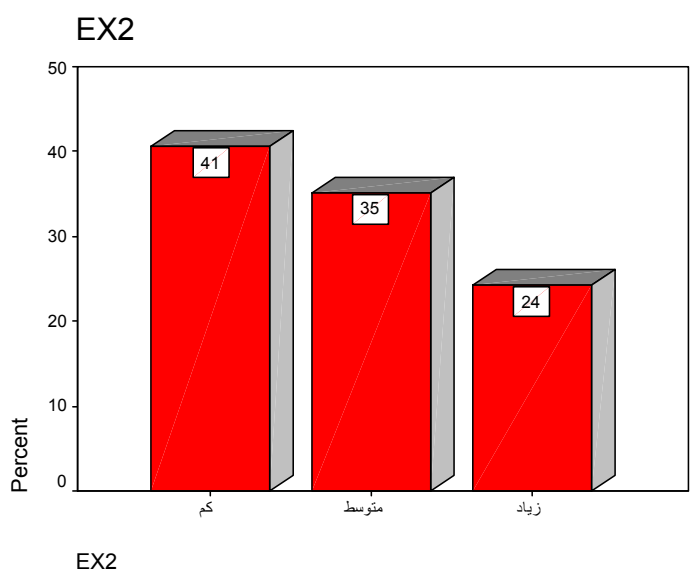

Figure 7. Frequency distribution and percentages Relevant to the Effect of learners' experience of failure 


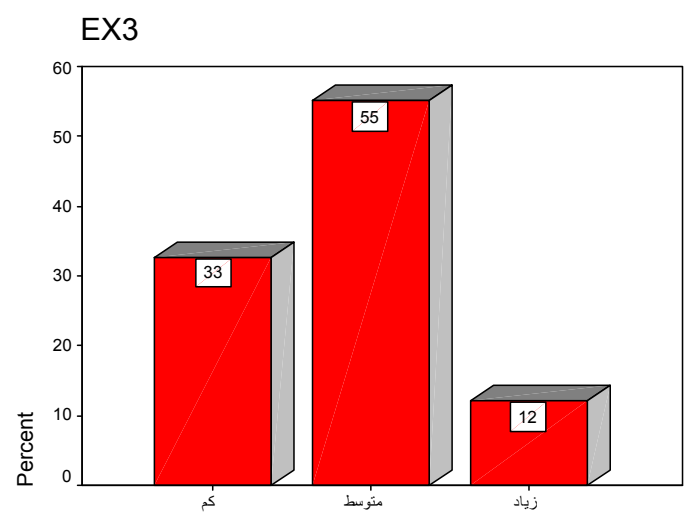

EX3

Figure 8. Frequency distribution and percentages Relevant to the Effect of learners' lack of success

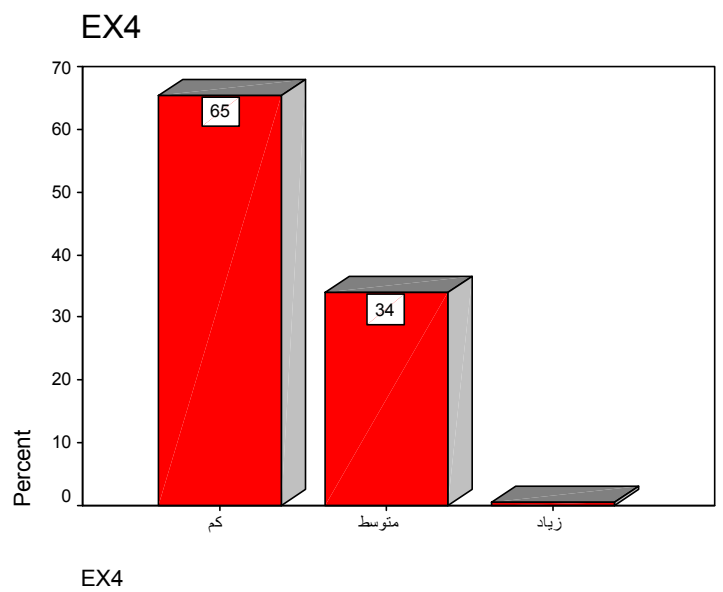

Figure 9. Frequency distribution and percentages Relevant to the Effect of learners' Attitude 